\title{
ČLÁNKY
}

\section{Dovolenkové právo v judikatúre Súdneho dvora EÚ pracovnoprávna úprava Zákonníka práce*}

\author{
Annual Leave in the Case Law of the Court of Justice \\ of the European Union and Legislation of the Labour Code
}

\author{
Helena Barancová**
}

\begin{abstract}
Abstrakt
Po prijati takmer 30 rozhodnutí Súdneho dvora EÚ osobitne za posledných desat' rokov v oblasti dovolenkového práva, je viac nežpotrebné sa zo strany slovenskej pracounoprávnej legislativy zaoberat' podstatními legislativnymi zmenami dovolenky tak, ako ju podla právneho stavu de lege lata zakotvije Zákonník práce Slovenskej republiky ale aj Zákonník práce Ceskej republiky.

Ako z. vyšsie uvedenej analýsy autora vidno, v najbližš́j budúcnosti je potrebné nanovo legislativne formulovat’ predpoklady væniku dovolenky za kalendárny rok a správne upravit’ jej osobnú pôsobnost.' Vychádzajúc zo záverov viacerých rozhodnuti Súdneho dvora týkajúcich sa ,dovolenkového práva", ktoréprikazujú členským

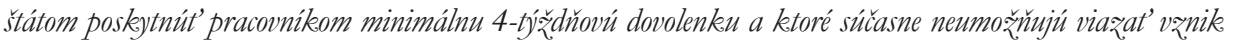
práva na dovolenku na odpracovanie určitého počtu dní (vid' najmä roz̧hodnutie SD EÚ v právnej veci BECTU, v práunej veci Schulz. Hof, ako aj v právnej veci Domingues), bude potrebné nanovo legislativne formulovat' predpoklady vaniku nároku na dovolenku za kalendárny rok. Dovolenku za odpracované dni by bolo potrebné vypustit' z. existujúcej pracounoprávnej úpravy Zákonníka práce, pretože nielen svojím názvom ale aj obsabom sa prieči zákeazu viazat'vanik nároku na dovolenku na odpracovanie príslušnébo počtu dni. Minimálna 4-týždňová dovolenka prishücha zamestnancovi už od prvébo dňa výkonu práce, aj ked’ pri čiastočnom pracounom úväzku sa vychádz̧a zo zásady pro rata temporis (najmä roz̧odnutie Súdneho dvora EÚ v právnej veci Heiman, bod 24 a rozhodnutie v právnej veci Zentralbetriebesrat der Landeskrankenbäuser Tirols, bod 27). Dovolenka má v zmysle smernice 2003/88/ES ako aj judikatúry Súdneho dvora EÚ pracovnikovi prishíchat' aj počas dočasnej práceneschopnosti (z. uvedenébo dôvodu by sa nemala krátit'), aj ked' samotný zamestnanec sa môžze roz̧hodnút’ neuplatnit' dovolenku počas dočasnej práceneschopnosti. Obdobne súladne s doterajšou judikatúrou Súdneho dvora bude treba upravit' celú problematiku krátenia dovolenky nielen pokial' ide o dôvody krátenia dovolenky, tak aj o rozsah krátenia dovolenky, ktorý, by nemal byt' pod úrovnou minimálnej ročnej dovolenky vyplývajúcej z článku 7 ods. 1 smernice 2003/88/ES, majúceho priamy právny účnok.
\end{abstract}

* Príspevok pripravený v rámci riešenia výskumného projektu APVV: „Nové technológie v pracovnom práve a ochrana zamestnanca“, zodp. riešitel'ka prof. JUDr. Helena Barancová, DrSc.

** Prof. JUDr. Helena Barancová, DrSc., Katedra pracovného práva a práva sociálneho zabezpečenia, Právnická fakulta, Trnavská univerzita v Trnave / Department of Labour Law and Social Security Law, Faculty of Law, Trnava University, Trnava, Slovak Republic / E-mail: hbaranc@truni.sk 
Osobitnú pozornost' bude treba venovat' problému kumulácie nadobudnutých práv zamestnanca, obmedzenie tejto kumulácie v pripade dlbodobej dočasnej práceneschopnosti pracovnike a oprávnenosti takejto kumulácie v prípade iných dôvodov, zvlást'v prípadoch, ked'samotný zamestnávatel' neumožní pracovníkovi

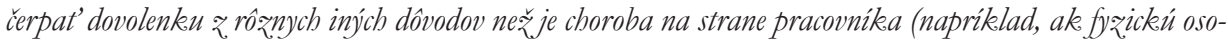
bu zamestnáva výkonom závislej práce ako ,živnostníka“), co bol aj najnovši pripad rozhodnutia Súdneho dvora EÚ v právnej veci King z. konca novembra 2017.

\section{Klíčová slova}

Dovolenkové právo; minimálna 4-tỹ̌̃unová dovolenka; pracovnici; Zákonník práce Slovenskej republiky; Zákonník. práce Ceskej republiky;; rozhodnutia Súdneho dvora EÚ; podmienky pre dovolenka; akumulácia dovolenky.

\section{Abstract}

After adoption nearly 30 decision of the Court of Justice of the EU in particular over the last decade in the sphere of the right to annual leave, it is more than necessary for the Slovak and Crech legislation to deal with the legislative changes of the holiday as laid down in the legal status de lege lata by the Labour Code of the Slovak. Republic and by the Labour Code of the Czech Republic.

As is clear from the author's analysis, in the near future, it is necessary to re-formulate legislative assumptions of annual leave. Based on the conclusions of several decisions of the Court of Justice of the EU concerning the "annual leave law", which requires the Member States to provide to workers a minimum 4-week. leave and which at the same time do not make it possible to link the entitlement to a leave to a certain number of days (see in particular the decision of Court of Justice in the case BECTU, Schulz-Hoff, as well as in case Domingues), it will be necessary to re-formulate the conditions for the entitlement to leave for a calendar year. Leave for days worked should be abolished from the existing employment legislation of the Labour Code, because not only by its name but also by the content is contrary to the probibition to bind entitlement to leave for the relevant number of days worked. Workers are entitled to a minimum 4-week boliday from the first day of work, although in part-time work is based on the principle of pro rata temporis (in particular the ruling of the Court of Justice in Heiman, paragraph 24 and the Zentralbetriebssrat der Landeskrankenbäuser Tirols). In accordance with Directive 2003/88/EC and the case-law of the Court of Justice of the European Union, a worker is also entitled to an annual leave during his/her temporary incapacity for work. (for that reason, it should not be cut), even if the worker can decide not to enforce leave during his/ her temporary incapacity for work. Similarly, in line with the Court's previous case-law, it will be necessary to adjust the whole issue of the reduction of leave not only as regards the reasons for the reduction of leave but also to the extent of the reduction in leave which should not be below the minimum annual leave resulting from Article 7 (1) of Directive 2003/88/EC, which has direct legal effect.

Particular attention will be paid to the problem of accumulation of acquired rights of workers, limiting the accumulation in case of long-term temporary incapacity of the worker and the possibility of such accumulation for other reasons, especially in cases where the employer himself does not allow workers to take leave for various reasons other than illness on the part of workers (for example, if a physical person employs a dependent job as a "self-employed") as was the dispute in the most recent case of the EU's Court of Justice ruling in the King's case in late November 2017.

\section{Keywords}

Annual Leave; Minimum 4-week Leave; Workers; Labour Code of the Slovak Rebublic; Labour Code of the Czech Republik; Case Law of the Court of Justice EU; Conditions of Leave; Accumulation of Anual. 


\section{Úvod}

Judikatúra Súdneho dvora EÚ v oblasti dovolenkového práva sa popri diskriminačnom práve v ostatných rokoch rozvijala najdynamickejšie. Na rozdiel od iných systematických častí pracovného práva pribudlo za posledných vyše 10 rokov takmer 30 rozhodnutí Súdneho dvora EÚ (d’alej len „SD EÚ“), z ktorých prevažujúca čast’ nebola doteraz premietnutá do pracovnoprávnej úpravy Slovenskej republiky ani do pracovnoprávnej úpravy Českej republiky. Nezáujem zákonodarcu o dosiahnutie kompatibility existujúcej pracovnoprávnej úpravy dovolenky s rozhodovacou činnost'ou SD EÚ je neobvyklá, pretože $\mathrm{v}$ iných systematických častiach pôsobenia práva EÚ a judikatúry SD EÚ je vplyv na národnú pracovnoprávnu úpravu podstatne výraznejší. Aj keby sa na prvý pohl'ad mohlo zdat', že v oblasti dovolenkového práva nemôžu byt' väčšie interpretačné a aplikačné problémy, jeden z posledných prípadov riešeným pred Súdnym dvorom EÚ v právnej veci King zo dňa 28. 11. 2017 ukázal na závažnost’ sociálnoprávnych dôsledkov porušenia pravidiel zamestnávatel'a nielen pri poskytovaní dovolenky zamestnanca, ale aj pri nesprávnom zarad'ovaní samostatne zárobkovo činných osôb na výkon závislej práce.

Právna vec King, riešená pred Súdnym dvorom EÚ súčasne ukázala aj na iné problémy dovolenkového práva, ktoré súvisia nielen s právnou povahou práva na dovolenku, ale aj s osobnou pôsobnost'ou smernice 2003/88/ES, s podmienkami vzniku práva na dovolenku, s uplatnením práva na dovolenku, s prenášaním dovolenky do nasledujúcich období a s tým súvisiacou kumuláciou práva na dovolenku, resp. jej peňažnej náhrady ako aj s d’alšími problémami.

\section{Všeobecný právny rámec}

Právo na dovolenku Ústava Slovenskej republiky zakotvuje v článku 36 v rámci katalógu ústavných sociálnych práv, ktorý zamestnancom garantuje najkratšiu prípustnú dížku platenej dovolenky. Nadväzujúc na článok 36 Ústavy Slovenskej republiky konkrétnejšiu právnu úpravu pokial ide o výmeru dovolenky zakotvuje Zákonník práce Slovenskej republiky v ustanovení \103, podl’a ktorého základná výmera dovolenky je najmenej štyri týždne. Dovolenku vo výmere najmenej piatich týždňov má zamestnanec, ktorý do konca príslušného roka dovŕši najmenej 33 rokov veku.

Zákonník práce SR formuluje právo na dovolenku zamestnanca relatívne kogentným spôsobom, ktorý zamestnávatel'a zaväzuje dodržat' zákonom ustanovenú minimálnu výmeru dovolenky a súčasne umožňuje bez akéhokol’vek zákonného obmedzenia poskytnút' zo strany zamestnávatel'a väčšiu výmeru dovolenky.

Podl'a právneho stavu de lege lata dovolenku zamestnanca možno vymedzit’ ako najvýznamnejsiu dobu odpočinku po vykonanej práci zamestnanca, ktorá je zo strany zamestnávatel'a hmotne zabezpečená poskytnutím nábrady mady vo výške jeho priemernébo zárobku. Svojím hmotným 
zabezpečením sa dovolenka odlišuje od iných druhov odpočinku, ktoré sú kratšie, pričom dovolenka má byt' dlhodobejším odpočinkom zamestnanca za vykonanú prácu v priebehu kalendárneho roka, preto zákonodarca podl’a právneho stavu de lege lata zaväzuje zamestnávatel’a, aby aspoň dva týždne dovolenky za príslušný rok poskytol zamestnancovi vcelku.

Spôsob využitia dovolenky Zákonník práce Slovenskej republiky ale aj Českej republiky neupravuje. Hlavným účelom dovolenky je zotavenie zamestnanca po celoročnom výkone práce. Dovolenka má číro osobnú povahu, preto smrt’ou zamestnanca zaniká nárok na dovolenku, nie však nárok na náhradu mzdy za nevyčerpanú dovolenku, na ktorú mu vznikol nárok do času smrti.

Dovolenka je najvýznamnejšou dobou odpočinku, v rámci ktorej je zamestnanec oslobodený od plnenia pracovných povinností.

Právo na dovolenku je ústavným právom, ktoré v sebe zahrnuje dva podstatné obsahové prvky, právo na pracovné volno a právo na hmotné zabezpečenie počas tohto pracovnébo volna. Právo na dovolenku takto poníma vo svojej doterajšej rozhodovacej činnosti aj Súdny dvor EÚ.

Právo na dovolenku ako ústavné právo treba odlišovat' od oprávnenia zamestnávatel'a určit' nástup na dovolenku, ktoré Zákonník práce zveruje výlučne do kompetencie zamestnávatel’a.

\subsection{Medzinárodná úprava ročnej dovolenky a úprava Európskej únie}

Právo na dovolenku popri vnútroštátnej právnej úprave má aj svoj medzinárodnoprávny základ. Podl'a článku 9 ods. 1 Dohovoru 132 Medzinárodnej organizácie práce o platenej ročnej dovolenke, ktorým je Slovenská aj Česká republika viazaná, neprerušená čast' platenej ročnej dovolenky sa musí poskytnút' a čerpat’ najneskôr v období jedného roka a zvyšná čast' nevyčerpanej dovolenky najneskôr do 18 mesiacov od skončenia roka, v ktorom vznikol nárok na dovolenku. V pracovnoprávnej úprave SR aj ČR uvedené právo na dočerpanie dovolenky je Zákonníkom práce ustanovené do konca nasledujúceho roka, v ktorom vzniklo právo na dovolenku, (t.j. do konca nasledujúceho kalendárneho roka).

Nárok na minimálnu ročnú dovolenku zakotvuje aj Európska sociálna charta ako aj Revidovaná Európska sociálna charta.

Na úrovni práva Európskej únie právo na dovolenku zakotvuje článok 31 ods. 2 Charty základných práv EÚ (d’alej len „Charty“), ktorej sa priznáva podl’a článku 6 Zmluvy o fungovaní Európskej únie rovnaká práv na sila ako zakladajúcim zmluvám, čo výslovne deklaroval aj Súdny dvor EÚ v právnej veci C-214/10, KHS, zo dňa 22. novembra 2011. Právo na dovolenku je predmetom úpravy aj sekundárneho práva EÚ, smernice 2003/88/ES (d’alej len „smernice 2003/88/ES“) o určitých aspektoch organizácie pracovného času, ktorá okrem minimálnych požiadaviek na organizáciu pracovného času 
z pohl’adu bezpečnosti a ochrany zdravia pri práci v článku 7 ods. 1 zakotvuje minimálnu dobu ročnej dovolenky pracovníkov na štyri týždne. Podl’a Charty aj predmetnej smernice osobný rozsah práva na dovolenku je zameraný na pracovníka, nie na zamestnanca, čo sú kvalitatívne odlišné právne pojmy. Pojem pracovník v żmysle práva EÚ je širšim pojmom než pojem zamestnanec. Z uvedenébo dôvodu pouřvivame v tomto článku pojem pracounik v żmysle, $v$ akom ho pouriviva smernica 2003/88/ES.

Podl’a článku 7 smernice 2003/88/ES členské štáty sú povinné prijat’ nevyhnutné opatrenia, ktoré zabezpečia, že každý pracovník bude mat' nárok na platenú ročnú dovolenku v trvaní najmenej štyroch týždňov v súlade s podmienkami pre vznik nároku a jej poskytovanie, ustanovené vnútroštátnymi právnymi predpismi alebo praxou. Vychádzajúc z hlavného účelu ročnej dovolenky nemôže byt' zo strany zamestnávatel’a vyplatená peňažná náhrada namiesto minimálnej ročnej dovolenky, s výnimkou prípadu skončenia pracovného pomeru. Ak by sme chceli zovšeobecnit' a vyhodnotit' stav a úroveň existujúcej pracovnoprávnej úpravy dovolenky v Zákonníku práce Slovenskej republiky, konštatujeme, že vo viacerých ohl’adoch je nekompatibilná s aktuálnou, ustálenou a početnou judikatúrou SD EÚ. Ide nielen o problém vzniku nároku na minimálnu ročnú dovolenku viazanú podl’a Zákonníka práce Slovenskej republiky na odpracovanie určitej doby, ale aj o problém nepriznania dovolenky zamestnancom pracujúcim na základe dohôd o prácach vykonávaných mimo pracovného pomeru, o problém krátenia dovolenky až pod hranicu jej minimálnej výmery právne zaručenej nielen Chartou základných práv EÚ ale aj smernicou 2003/88/ES, či o problém výmery dovolenky viazaný v zmysle slovenskej pracovnoprávnej úpravy výlučne na dosiahnutie určitého veku. Pod vplyvom najnovšej judikatúry SD EÚ k problémom, ktorý je hodný aj legislatívneho stvárnenia v pracovnoprávnej normotvorbe, je aj kumulácia nárokov na dovolenku prenášanú z predchádzajúcich rokov Súdnym dvorom odlišne riešenú v prípadoch nevyčerpania dovolenky z dôvodu choroby a nevyčerpania dovolenky z iných dôvodov, v ktorých si zamestnanec nemohol vyčerpat' dovolenku, lebo mu ju zamestnávatel' odmietol poskytnút' ako aj požiadavka zákonodarcu na odpracovanie určitého počtu dni ako podmienku vzniku nároku na dovolenku.

Najnovší prípad riešený pred SD EÚ v právnej veci King zaväzuje zamestnávatela k poskytnutiu dovolenky aj za viac po sebe nasledujúcich rokov aj v prípade fyzickej osoby, ktorú firma zamestnávala ako samostatne zárobkovo činnú osobu, aj ked’ vykonávala závislú prácu. Na uplatnenie práva na dovolenku za kumulované obdobie aj pre takéto „osoby so statusom samostatne zárobkovo činnej osoby“ vykonávajúce závislú prácu nič nemení ani skutočnost’, že sa obidve zmluvné strany takto zmluvne dohodli na začiatku výkonu práce. ${ }^{1}$

1 PREIS, U. a A. SAGAN. Europäisches Arbeitsrecht. Köln: Ottoschmidt, 2015, s. 412-416; FUCHS, M. a F. MARHOLD. Europäisches Arbeitsrecht. 4. Auflage. Verlag Österreich, 2014, s. 480 a nasl. 


\section{Právna vec King}

Súdny dvor EÚ v právnej veci King rozhodol, že pánovi Kingovi patrí dovolenka za vyše 13 rokov výkonu práce vo firme, aj ked' vykonával svoju prácu v právnom postavení samostatne zárobkovo činnej osoby. A ked’že túto dovolenku si pán King už nemohol vyčerpat' z dôvodu skončenia svojej pracovnej činnosti odchodom do starobného dôchodku, svoj právny nárok za nevyčerpanú dovolenku si uplatnil vo forme peňažnej náhrady. Spoločnost' Sash WW, v ktorej pán King pracoval v postavení samostatne zárobkovo činnej osoby, mu po celú dobu výkonu práce neposkytovala dovolenku, aj ked' pán King počas svojej činnosti pre firmu čerpal určité neplatené pracovné vol'no bez finančného krytia. Namiesto mzdy mu spoločnost' poskytovala za prácu provízie.

Právny nárok pána Kinga na vyplatenie peňažnej náhrady za nevyčerpanú dovolenku predstavoval za všetky roky trvania jeho pracovnej činnosti vo firme od 1. júna 1999 do 6. októbra 2012. ${ }^{2}$

V súdnom spore na národnej úrovni už príslušný pracovný súd (Employment Tribunal) vo svojom rozhodnutí konštatoval, že pán King mal byt’ považovaný za „pracovníka“ v zmysle smernice 2003/88/ES, a že mu vznikol nárok na platenú dovolenku za príslušné kalendárne roky. Odvolací súd predložil uvedenú kauzu Súdnemu dvoru s prejudiciálnymi otázkami týkajúcimi sa oprávnenosti nároku na dovolenku fyzickej osoby, ktorá nebola s predmetnou firmou formálne v pracovnom pomere ako aj s d'alšími otázkami.

Súdny dvor EÚ vo vyššie uvedenej veci rozhodol, že pán King má nárok na dovolenku za kalendárne roky, ktorú mu firma (zamestnávatel') odmietala poskytovat' z právneho titulu postavenia samostatne zárobkovo činnej osoby a v právnej vete uvedeného rozsudku výslovne vyjadril, že v rozpore s článkom 7 smernice 2003/88/ES sú také ustanovenia vnútrošátneho práva, podla ktorých pracovnik nemôže preniest' ani prípadne kumulovat' nároky na dovolenku až do momentu skončenia pracovnébo pomeru, k.toré nevyčerpal v rámci viacerých po sebe nasledujúcich referenčných obdobi z dôvodu odmietnutia zamestnávatel'a poskytnút peñažnú nábradu za túto dovolenku.

\subsection{Právne následky rozsudku Súdneho dvora v právnej veci King}

Nervozita zo strany podnikatel’skej praxe v dôsledku citovaného rozsudku vychádza z obavy, žeby súdy členských štátov EÚ mohli do budúcnosti priznat' nároky na dovolenku aj so spiatočnou platnost’ou fyzickým osobám, ktoré síce vykonávali závislú prácu, ale, boli v postavení samostatne zárobkovo činnej osoby. Išlo by aj o právne situácie, ak by sa zmluvné strany sami dohodli, že fyzická osoba bude pre konkrétnu firmu vykonávat' závislú prácu v statuse samostatne zárobkovo činnej osoby. Podl’a SD EÚ aj preukázaná okolnost', že sa Sash WW nesprávne domnievala, že pán King nemal právo

2 C-214/2016, King, zo dňa 29. 11. 2017. 
na platenú dovolenku za kalendárny rok z dôvodu statusu samostatne zárobkovo činnej osoby, nie je právne relevantná, pretože podl’a Súdneho dvora EÚ: „, je úlohou zamestnávatel'a, aby si zistil v'setky informácie týkeajúce sa jeho povinností v tejto oblasti. "3 Obdobne podl'a SD EÚ nie je relevantnou ani otázka, či pán King v priebehu času pred skončením zamestnania požiadal alebo nepožiadal o čerpanie platenej dovolenky. ${ }^{4}$

Pre aplikačnú prax bolo nesporne prekvapením nielen to, že Súdny dvor priznal právo na dovolenku za vyše 13 rokov výkonu práce fyzickej osobe, ktorá mala status samostatne zárobkovo činnej osoby, ale aj skutočnost', že uznal „masívnu“ kumuláciu nárokov za viac po sebe nasledujúcich rokov, ${ }^{5}$ aj ked' v právnej veci C-214/10, KHS, túto kumuláciu nárokov pracovníka uznal za neoprávnenú, ak bola spôsobená z dôvodu choroby na strane zamestnanca a nesúvisela so skončením pracovného pomeru. ${ }^{6}$

Súdny dvor v právnej veci King sám upozorňuje na rozdielnosti v oprávnenosti či neoprávnenosti poskytnutia dovolenky, resp. peňažnej náhrady za jej neposkytnutie aj za kumulované referenčné obdobia tým, že výslovne uvádza, že: „na rożdiel od situácie možnosti obmedženia kumulácie práva na platenú ročnú dovolenku pracovnika, ktorý nemôže čerpat túto dovolenku z. dôvodu choroby (C-214/10, KHS, je zamestnávatel', ktorý neumožni pracovníkovi vykonat' jeho právo na platenú ročnú dovolenku, povinný znášat' následky a teda poskytnút’ zamestnancovi nábradu mzdy aj za viac kumulovaných obdobi, v ktorých zamestnancovi vznikol nárok na dovolenku "7

Riziko d’alekosiahlych právnych následkov uvedeného rozsudku SD EÚ pre aplikačnú prax nielen v Slovenskej republike ale aj v iných členských štátoch, ktorých podnikatelia využívajú na výkon závislej práce „živnostníkov z donútenia“ vyplýva aj zo skutočnosti, že SD EÚ v ňom rozhodol, že ak dovolenku zamestnávatel’ príslušnej fyzickej osobe nepriznal, odmietol ju poskytnút', resp. ani nevedel, že ju má poskytnút', napriek tomu pracovníkovi prislúcha náhrada mzdy aj za viac kumulovaných období predchádzajúcich kalendárnych rokov pred skončením pracovného viazania k príslušnej firme či už bol v pozícii živnostníka alebo v pozícii pracovníka. Právne následky uvedeného rozsudku spočívajú okrem iného v možnosti prekvalifikácie statusu osoby samostatne zárobkovo činnej na status pracovníka v prípade súdneho sporu a s nimi spojené sociálnoprávne nároky. Ide o obdobnú situáciu ako prípad americkej spoločnosti Microsoft vo veci priznania statusu zamestnanec pre osoby samostatne zárobkovo činné so spiatočnou účinnost'ou. ${ }^{8}$

3 C-214/2016, King, zo dňa 29. 11. 2017, bod 56.

4 Ibid., ako aj právna vec C-118/2014, Bollacke, zo dňa 12. 6. 2014.

5 Podl’a SD EÚ nárok vznikol až po skončení pracovnej činnosti, preto ho Súd nepovažoval za premlčaný.

6 C-214/10, KHS, zo dňa 22. 11. 2011.

7 C-214/10, KHS, zo dňa 22. 11. 2011, bod 64.

8 Okresný súd USA, západný okres Washington, Seattle, Viz̨aino a d’alši verzus Microsoft Corporation, Dohoda o urovnaní skupinovej žaloby, 8. december 2000, Odvolací súd Spojených štátov pre Deviaty obvod, č. 01-35494 zo dňa 15. 5. 2002. 
Obmedzenie kumulácie poskytnutia dovolenky za viac referenčných období a jej finančné krytie sa podl'a doterajšej judikatúry SD EÚ vzt'ahuje len na nemožnost' čerpania dovolenky z dôvodu choroby vo fungujúcom pracovnom vzt'ahu, ktorá spôsobila dlhodobú práceneschopnost' pracovníka. Ide o právne situácie, pri ktorých zamestnanec nemal možnost' vykonat' svoje právo na uvedenú dovolenku z dôvodu choroby (49), čo nie je prípad právnej veci King. ${ }^{9}$

Za osobitných okolností akými sú choroba pracovníka, ktorá trvá počas niekol'kých po sebe nasledujúcich referenčných období nielen vzhl’adom na ochranu pracovníka, ale aj na ochranu zamestnávatel’a vystaveného nebezpečenstvu neprimeraného kumulovania období neprítomnosti pracovníka na pracovisku, a na nepríjemnosti, ktoré z toho môžu vyplývat' pre organizáciu práce, článok 7 smernice 2003/88/ES sa podl'a SD EÚ má vykladat' v tom zmysle, že nebráni vnútroštátnym ustanoveniam alebo vnútroštátnej praxi, k.toré obmedzujú kumulovanie práv na platenú dovolenku za kalendárny rok pracovnikea, ktorý je práceneschopný počas niekol'kých po sebe nasledujücich referenčných obdobi, tým, že stanovujú lehotu pätnástich mesiacov, po uplynuti k.torej zanikne právo na platenú dovolenku za kalendárny rok.. ${ }^{10}$

Ako SD EÚ v právnej veci King výslovne vyjadril, „Na rozdiel od právnej veci KHS v právnej veci King ochrana záujmov zamestnávatel'a sa nejavi ako nevyhnutne potrebná, a tým ani spôsobilá odôvodnit výnimku z. práva na platenú dovolenku za kalendárny rok pracovnika (bod 59). Ak by sa naopak pripustilo, že došlo k zániku pracovníkom nadobudnutých práv na platenú dovolenku za kalendárny rok, znamenalo by to odobrenie správania sa zamestnávatel'a smerujúce k neoprávnenému obohateniu v rozpore so samotným ciel’om smernice, ktorý sleduje zabezpečenie zdravia pracovníka.

\section{Problémy spojené so vznikom práva na minimálnu dovolenku za kalendárny rok podl’a judikatúry SD EÚ}

Právo na dovolenku ako vyplýva z ustálenej judikatúry SD EÚ, vzniká priamo z článku 7 ods. 1 smernice 2003/88/ES, ktorému SD EÚ priznal priamu právnu účinnost'. Samotné znenie článku 7 ods. 1 smernice 2003/88/ES nepripúšt’a zo strany členských štátov žiadne výnimky. ${ }^{11}$ Súdny dvor považuje právo na minimálnu ročnú dovolenku za mimoriadne dôležitú zásadu sociálneho práva Únie, ktorú príslušné vnútroštátne orgány môžu uplatňovat' len v medziach výslovne uvedených samotnou smernicou 2003/88/ES. ${ }^{12}$

V zmysle aktuálnej judikatúry členským štátom EÚ prislúcha právo definovat’ len podmienky výkonu a uplatňovania práva na platenú dovolenku za kalendárny rok. Nie sú však oprávnené ustanovit' nijakú podmienku samotného vzniku práva na dovolenku

9 C-214/2016, King, zo dňa 29. 11. 2017.

10 C-214/10, KHS, zo dňa 22. 11. 2011, body 38, 43, 44.

11 C-173/99, BECTU), zo dňa 26. 6. 2001, bod 43.

12 Ibid. 
(C-214/2016, King, bod 34, C-350/06 a C-520/0, SchultzHoff a i., bod 28). Smernica 2003/88/ES preto neumožňuje členským štátom vylúčit' vznik práva na platenú dovolenku za kalendárny rok, ani ustanovit', že právo na platenú dovolenku pracovníka, ktorý ho nemohol uplatnit', zanikne uplynutím referenčného obdobia a/alebo obdobia na prenesenie dovolenky upraveného vnútroštátnym právom (právna vec C-350/06 a C-520/06, SchultzHoff a i., zo dňa 20. januára 2009, body 47 a 48).

\section{Povaha práva pracovníka na dovolenku}

Smernica 2003/88/ES chápe právo na dovolenku za kalendárny rok a právo na peňažnú náhradu za dovolenku ako dve zložky jediného práva, ktoré má súčasne povahu základnej zásady sociálneho práva a článok 31 ods. 2 Charty základných práv EÚ mu priznáva súčasne charakter základného práva. ${ }^{13}$ Ciel' poskytnutia peňažnej náhrady počas dovolenky spočíva v tom, aby pracovník počas čerpania dovolenky bol v porovnatel’nej príjmovej situácii, ako v období, ked’ plní svoje pracovné úlohy (C-539/12, Lock, zo dňa 22. mája 2014, bod 17).

Samotným ciel'om práva na platenú dovolenku za kalendárny rok je umožnit' pracovníkovi odpočinút' si a zotavit' sa.

Ako však uviedla Európska komisia vo svojich písomných pripomienkach v právnej veci King, pokial' by bol pracovník počas čerpania svojej dovolenky za kalendárny rok vystavený okolnostiam, ktoré môžu vyvolávat' neistotu v súvislosti s poskytnutím odmeny, ktorá mu patrí, nemôže plne využit' uvedenú dovolenku ako čas na oddych a zotavenie podl'a článku 7 smernice 2003/88/ES. Takéto okolnosti môžu tiež odradit' pracovníka od čerpania dovolenky za kalendárny rok. Každá činnost' alebo nečinnost’ zamestnávatel'a, ktorá má potenciálne odradzujúci účinok na čerpanie dovolenky za kalendárny rok, je v rozpore s účelom práva na platenú dovolenku za kalendárny rok (C-539/12, Lock, zo dňa 22. mája 2014, bod 29).

\section{Osobná pôsobnost' smernice}

Osobná pôsobnost' smernice 2003/88/ES je mimoriadne významná, pretože určuje okruh oprávnených subjektov, adresátov, ktorým je určená smernica. Smernica vychádza z vel’mi extenzívneho ponímania pojmu pracovník, obdobne ako Rámcová smernica 89/391/EHS o bezpečnosti a ochrane zdravia pri práci.

$\mathrm{V}$ samotnom texte smernice nie je síce pojem pracovník presne definovaný, ale jeho obsahové ohraničenie je dané rozvinutou judikatúrou SD EÚ, ktorá prisudzuje osobnej pôsobnosti smernice vel'mi široký, extenzívny výklad poukazujúc na ponímanie pojmu

13 C-155/10, Wiliams, zo dňa 15. 9. 2011, C-337/10, Neidel, zo dňa 3. 5. 2012, C-214/10, KHS, zo dňa 22. 11.2011. 
pracovník v rozhodnutí C-66/85 (Lawrie Blum) zo dňa 3. 7. 1986, bod 86 alebo v rozhodnutí C-138/02 (Collins) zo dňa 23. 3. 2004, bod 26.

Podl'a aktuálnej judikatúry SD EÚ pojem pracovník pre úcely bezpečnosti a ochrany zdravia pri práci je autonómnym pojmom práva EÚ a obsahová sírka tohto pojmu sa prekrýva s pojmom pracovnik tak, ako ho zakotvije clánok 45 Zmluvy o fungovani EÚ pre úcely volného pobybu pracovníkov. Za „pracovníka“ je podl’a judikatúry SD EÚ potrebné považovat' každého, kto vykonáva skutočné a konkrétne činnosti, s výnimkou činností, ktoré sú tak obmedzené, že sa javia ako čisto okrajové a vedl'ajšie. Charakteristickou črtou pracovného vzt’ahu pracovníka je okolnost', že fyzická osoba vykonáva pracovné úlohy počas určitého času v prospech inej osoby a pod jej vedením, za čo dostáva odmenu (pozri najmä rozsudky C-66/85, LawrieBlum, zo dňa 3. 7. 1986, body 16 a 17; C-138/02 (Collins) zo dňa 23. 3. 2004, bod 26, C-456/02, Trojani, zo dňa 7. 9. 2004, bod 15). ${ }^{14}$

Do obsahového rámca pojmu pracovník v zmysle práva EÚ sa majú podla existujúcej judikatúry SD EÚ zahrnovat’ aj fyzické osoby, ktoré pracujú v príležitostných alebo sezónnych prácach (vid’ rozsudok Union syndikale Solidaires Isére, body 25-28, tiež rozsudok BECTU bod 45 a rozsudok Pfeifer, bod 52). Podl'a Uznesenia Súdneho dvora EÚ v právnej veci C-519/09, May, zo dňa 4. 2. 2011 pojem „pracovník“ zahrnuje aj osobu verejnoprávneho subjektu v oblasti verejného práva, pretože pôsobnost' smernice 2003/88/ES sa vzt'ahuje na všetky odvetvia činnosti, súkromnoprávne aj verejnoprávne. Obdobne širší pojem „pracovník“ vyložil Súdny dvor EÚ v právnej veci C-316/13, Fenoll, zo dňa 26. 3. 2015, podl’a ktorého článok 7 smernice 2003/88/ES ako aj článok 31 ods. 2 Charty základných práv EÚ sa má vykladat' v tom zmysle, že môže zahrnovat' aj osobu prijatú do rehabilitačného Centra pomoci, ktorá zdravotnú rehabilitáciu uskutočňovala pomocou práce. Pán Fenol poskytoval určité práce Centru pomoci, ktoré boli spojené s podporou lekársko-sociálnej povahy. Tieto práce boli riadené a pridelované personálom ako aj vedením Centra pomoci, ktoré sa snažilo pánovi Fenol prostredníctvom určitých druhov pracovných výkonov umožnit' spôsob života, ktoré by najlepšie zodpovedali jeho potrebám. Úlohy, ktoré plnili aj iné osoby s t’ažkým zdravotným postihnutím v prospech Centra pomoci, predstavovali pre Centrum pomoci určitý hospodársky úžitok, aj ked’ ich pracovné výkony produktivitou nezodpovedali pracovným výkonom zdravých osôb a neboli tak ani honorované. Boli hlboko pod úrovňou minimálnej mzdy. Súdny dvor vo veci vzniku práva na dovolenku žalobcov neuznal obranu Centra pomoci, že ide o čisto okrajové a vedl'ajšie činnosti (bod 35, 36 a 37) a priznal osobe s t’ažkým zdravotným postihnutím pánovi Fenol právo na dovolenku. V bode 25 uvedeného rozhodnutia Súdny dvor opät’ zdôraznil, že „na úcely smernice 2003/88/ES sa pojem „pracov-

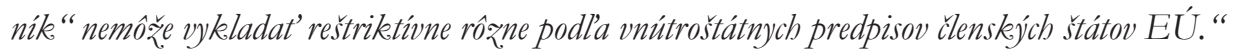


Rovnako do osobnej pôsobnosti smernice v zmysle aktuálnej judikatúry SD EÚ prislúchajú aj praktikanti a učni, aj ked’ ide o pracovnoprávne vzt’ahy sui generis, ktoré nepodliehajú niektorým ustanoveniam vnútroštátneho pracovného práva (pozri tiež právnu vec C-116/06 (Kïski) zo dňa 20. 9. 2007).

Z uvedeného vel'mi širokého osobného rozsahu vyplýva, že európsky zákonodarca mal v jasnom úmysle včlenit' pod osobnú pôsobnost' smernice nielen štandardné pracovnoprávne vzt’ahy, akým je pracovný pomer na ustanovený týždenný pracovný čas, tak aj pracovné pomery na čiastočný úväzok či príležitostnú alebo sezónnu prácu.

Osobný rozsah pojmu pracovník v zmysle aktuálnej judikatúry SD EÚ je daný Rámcovou smernicou 1968/391/EHS, ktorá vychádza z pojmu pracovník ako autonómneho pojmu práva EÚ a v zmysle ustálenej judikatúry SD EÚ sa obsahovo prekrýva s pojmom pracovník tak, ako je zakotvený v článku 45 Zmluvy o fungovaní EÚ.

$\mathrm{S}$ týmto celkom zrejmým a jasným úmyslom európskeho zákonodarcu nekorešponduje existujúca slovenská ako aj česká pracovnoprávna úprava Zákonníka práce, ktorá podl'a súčasného právneho stavu neumožňuje priznat' právny nárok na minimálnu platenú dovolenku za kalendárny rok zamestnancom vykonávajúcim prácu na základe dohôd o prácach vykonávaných mimo pracovného pomeru a to aj napriek tomu, že ide jasne o pracovnoprávny vzt’ah so subjektom, ktorého samotný Zákonník práce nazýva zamestnancom.

Z vyššie uvedeného doterajšieho legislatívneho rámca premietnutého do aktuálneho znenia Zákonníka práce Slovenskej republiky vyplývajú vel'mi významné sociálnoprávne následky v prípadoch vzniku budúcich pracovnoprávnych sporov, pri ktorých je sudca povinný uplatnit' eurokonformný výklad v súlade s naplnením základných ciel'ov smernice 2003/88/ES ako aj v súlade s článkom 31 ods. 2 Charty a aktuálnej početnej judikatúry SD EÚ.

\section{6 Čakacia doba pre účely dovolenky a iné podmienky vzniku nároku na dovolenku}

Ako vyplýva zo znenia smernice 2003/88/ES a z judikatúry SD EÚ, členským štátom prislúcha právo definovat' vo svojej vnútroštátnej právnej úprave podmienky výkonu a uplatňovania práva na dovolenku spolu so spresnením konkrétnych podmienok, za ktorých zamestnanci môžu využit' toto právo. Jedinou podmienkou vzniku nároku na minimálnu dovolenku za kalendárny rok je existencia pracovného vzt’ahu s oprávneným subjektom, ktorý má právny status pracovník. V zmysle smernice 2003/88/ES ako aj ustálenej judikatúry SD EÚ právny nárok na dovolenku vzniká pracovníkovi už od prvého dňa nástupu do práce. Pre vznik uvedeného právneho nároku sa nevyžaduje žiadna čakacia doba ani povinnost' skutočného odpracovania minimálneho počtu dní. Vo výrokovej časti v právnej veci Dominguez Súdny dvor výslovne vyjadril, 
že v zmysle článku 7 smernice 2003/88/ES sa neumožňuje členskému štátu prijat' také vnútroštátne právne pravidlá, podl’a ktorých pracovníkovi nevznikne právo na dovolenku za kalendárny rok skôr, kým neuplynie 13 týždňové minimálne obdobie nepretržitého zamestnania u toho istého zamestnávatel'a. ${ }^{15} \mathrm{~V}$ rozpore s článkom 7 smernice 2003/88/ES sú podl’a Súdneho dvora EÚ aj také vnútroštátne ustanovenia, podl'a ktorých právo na platenú dovolenku za kalendárny rok podlieha počas referenčného obdobia podmienke skutočného výkonu práce v minimálnej dĺžke 10 dní alebo jeden mesiac. ${ }^{16}$ Aj ked' niektoré členské štáty zakotvujú pre účely vzniku nároku na dovolenku ako podmienku odpracovanie určitého času, v zmysle smernice a aktuálnej judikatúry Súdneho dvora takéto úpravy členských štátov sú v rozpore so smernicou. Nárok na minimálnu stuortýždnovú platenú dovolenku za kalendárny rok vaniká v zmysle práva EÚ už prvým dñom začatia výkonu práce pracounikea. Clánok 7 smernice nezakotvuje pre v₹nik minimálnej ročnej platenej dovolenky řiadnu d’alšu podmienku, napr. určitý počet skutočne odpracovaných dní, čakaciu dobu, prípadne d’alšie podmienky. Súdny dvor EÚ užv právnej veci BECTU konštatoval, že členské štáty si nemôzu stanovit nijaké podmienky vžniku práva na minimálnu ročnú dovolenku, pretože toto právo vyplýva priamo z. uvedenej smernice. V znik nároku na minimálnu ročnú dovolenku nemôže byt' závisly od minimálnej doby zamestnania. Takéto úpravy by mobli viest’ $k$ zneug̃itiu zo strany zamestnávatel'a, aby s ciel'om neposkytnút' dovolenku za kalendárny rok uzatváral len krátkodobé pracovné pomery. Z uvedeného rozhodnutia SD EÚ vyplýva, že právo na platenú dovolenku za kalendárny rok je priznané samotnou smernicou 2003/88/ES všetkým pracovníkom (rozsudok BECTU, body 52 a 53) a nemôže podliehat' podmienke členského štátu, ktorá sa týka povinnosti skutočne odpracovanej doby počas referenčného obdobia (bod 41 rozhodnutia).

Aj podl'a d’alších rozhodnutí Súdneho dvora EÚ právny nárok zamestnanca na minimálnu štvortýždňovú platenú dovolenku v kalendárnom roku nie je súčasne závislý od okolnosti, či zamestnanec skutočne pracuje alebo je z dôvodu choroby práceneschopný. ${ }^{17}$ Podl'a bodu 41 rozhodnutia Súdneho dvora v právnej veci C-350/05, Schultz-Hof a d’alší, právo na minimálnu ročnú dovolenku smernica priznáva aj dočasne práce neschopným zamestnancom.

Slovenská pracovnoprávna úprava $\mathrm{v}$ Zákonníku práce tým, že viaže vznik nároku na dovolenku za kalendárny rok na odpracovanie 60 dní a dovolenky za odpracované dni na odpracovanie 21 dní, je nesúladná s článkom 31 ods. 2 Charty a tiež s článkom 7 smernice 2003/88/ES. Pritom podmienku príslušného počtu odpracovaných dní je podla

15 C-173/99, BECTU, zo dňa 26. 6. 2001 ako aj C-282/10, Dominguez, zo dňa 24. 01. 2012, k tomu problému pozri tiež literatúru: WIERFELD, J. Jahresurlaub unabhänging von einer Mindestarbeitszeit, Europäisches Zeitschrift für Arbeitsrecht, 2012, s. 540; LOESCHNIGG, G. Arbeitsrecht. 13. Auflage. Wien: OGB Verlag, 2017.

16 Ibid.

17 C-350/06, Schultz-Hoff a d'alší, zo dňa 20. 1. 2009, bod 41 a nasl. 
Zákonníka práce Slovenskej republiky potrebné splnit’ v každom kalendárnom roku, aj ked’ je zamestnanec $\mathrm{v}$ pracovnom pomere $\mathrm{k}$ zamestnávatel'ovi dlhší čas.

Aj z uvedeného vyplýva, že právo na dovolenku za odpracované dni by malo byt' zo Zákonníka práce vypustené. Ak odpracovanie 60 dní ako podmienka vzniku práva na dovolenku za kalendárny rok nie je právne korektné, obdobne je právne nekorektné vyžadovat' skutočné odpracovanie 21 dní pre vznik nároku na dovolenku za kalendárne dni.

\section{Kumulácia nárokov na dovolenku pri neprítomnosti $v$ práci $z$ dôvodu choroby}

V rozvoji dovolenkového práva Európskej únie má rozhodnutie v právnej veci Schulz-Hoff-Stringer podstatný právny význam. Podl'a uvedeného rozhodnutia členské štáty EÚ nesmú autonómne rozhodnút' o podmienenom vzniku a zániku nároku na ročnú platenú dovolenku.

\subsection{K skutkovému stavu}

Súdny dvor v uvedenej právnej veci rozhodol, že článok 7 ods. 1 smernice 2003/88/ES sa vykladat' tak, že zamestnanci musia mat'v každom prípade nárok na platenú ročnú dovolenku v trvaní najmenej štyroch týždňov a ak zamestnanec dovolenku nevyčerpal z dôvodu choroby, ktorá trvala počas celého referenčného obdobia, musí byt' dovolenka poskytnutá neskôr. Vnútroštátne právne predpisy a/alebo prax môžu stanovit', že nárok na platenú ročnú dovolenku zanikne, ak sa zamestnanci v referenčnom období pred poskytnutím dovolenky stali práceneschopnými pre chorobu a práceneschopnými zostali až do skončenia referenčného obdobia, resp. obdobia na prenesenie dovolenky stanoveného zákonom, kolektívnou zmluvou alebo individuálnou zmluvou.

Ciel'om práva na platenú ročnú dovolenku podl’a Súdneho dvora EÚ je umožnit' zamestnancovi odpočinút' si a poskytnút' mu čas na oddych a zotavenie po práci. Tento ciel' sa odlišuje od ciel'a sledovaného právom na pracovné vol'no z dôvodu choroby (práceneschopnosti) zamestnanca. Vychádzajúc z rôzneho účelu pracovnej neschopnosti a s ním súvisiaceho poskytnutého pracovného vol'na a na druhej strane z účelu dovolenky, ktorým je zotavenie zamestnanca, členský štát môže zakotvit', že zamestnanec nemusí čerpat' platenú ročnú dovolenku počas obdobia trvania dočasnej práceneschopnosti. Na druhej strane smernica 2003/88/ES nebráni takým vnútroštátnym ustanoveniam alebo praxi, ktoré umožňujú čerpat’ platenú ročnú dovolenku aj počas obdobia práceneschopnosti (bod 31 rozhodnutia).

Podl'a Súdneho dvora pripustit' skutočnost', že za osobitných okolností práceneschopnosti pracovníka vnútroštátne ustanovenia môžu stanovit' zánik práva zamestnanca na platenú ročnú minimálnu dovolenku zaručenú článkom 7 ods. 1 smernice 
2003/88/ES bez toho, aby zamestnanec v skutočnosti mal možnost' uplatnit' právo priznané touto smernicou, by znamenalo, že uvedené ustanovenia porušujú sociálne právo priznané každému pracovníkovi priamo článkom 7 tejto smernice (bod 45 vyššie citovaného rozhodnutia).

$V$ zmysle rozhodnutia v právnej veci C-194/12, Garcia, je v rozpore s právom EÚ taká vnútroštátna úprava, k.torá stanovije, že právo na platenú minimálnu dovolenku za kalendárny rok zanikne uplynutim referenčného obdobia alebo obdobia na prenesenie dovolenky ustanovenébo vnútroštátnym právom, aj keed' zamestnanec bol na nemocenskej dovolenke počas celébo referenčného obdobia alebo počas jeho ćasti a jeho práceneschopnost' trvala až do skončenia pracounébo pomeru, a preto nemal možnost' uskutočnit' svoje právo na platenú ročnú dovolenku. ${ }^{18}$

V právnej veci Neidel pán Neidel si nemohol z dôvodu dočasnej pracovnej neschopnosti vyčerpat' načas dovolenku (2 roky PN). Po ukončení pracovnej neschopnosti odchádzal do dôchodku s nevyčerpanou dovolenku. Súdny dvor rozhodol, že pracovník má nárok na vyplatenie peňažnej náhrady za nevyčerpanú dovolenku. Súdny dvor súčasne potvrdil, že roz̧odujúce nábradné obdobie pre uplatnenie nároku na ročnú platenú dovolenku určené na 9 mesiacov po uplynutí referenčného obdobia nie je dostačujúce. V zmysle predmetného rozhodnutia sú vnútroštátne predpisy členského štátu v rozpore s článkom 7 smernice 2003/88/ES, ak obmedzujú právo pracovníka odchádzajúceho do dôchodku peňažnú náhradu za kumulované nároky za nevyčerpanú dovolenku, ktorú si nemohol vyčerpat' z dôvodu práceneschopnosti pre chorobu tým, že uplynutím tejto lehoty mu zaniká právo na dovolenku za kalendárny rok.

Vo výrokovej časti ako aj bode 38 právnej veci C-214/10, KHS, Súdny dvor na druhej strane vyjadril, že lehota na zánik nároku na dovolenku za kalendárny rok, ktorú pracovník nemohol vyčerpat' z dôvodu práceneschopnosti pre chorobu ustanovená na 15 mesiacov po uplynutí referenčného obdobia je dostačujúca pre zánik nároku na dovolenku vo fungujúcom pracovnom vzt’ahu. Ide však o situácie kumulovania právneho nároku na dovolenku za kalendárny rok z dôvodu práceneschopnosti pracovníka, ktorý si pre chorobu nemohol načas vyčerpat' dovolenku.

\subsection{Právna vec KHS $^{19}$}

V teórii sa rozhodnutie v právnej veci $K H S$ považuje za vel’mi významnú modifikáciu rozhodnutia Schulz-Hoff-Stringer. V tomto rozhodnutí Súdny dvor vyslovil, že členský štát je oprávnený určit’ maximálnu dobu, v rámci ktorej si môže práceneschopný zamestnanec uplatnit' svoje právo na minimálnu ročnú dovolenku v trvaní 4 týždňov a „náhradnú“ dobu na vyčerpanie dovolenky v trvaní 15 mesiacov po uplynutí príslušného

\footnotetext{
18 Na rozdiel od právnej veci KHS ide o chorobu pracovníka trvajúcu až do skončenia referenčného obdobia, ktoré je spojené súčasne so skončením pracovného pomeru).

19 C-214/10, KHS, zo dňa 22. 11. 2011.
} 
roka vzniku nároku na dovolenku (po uplynutí referenčného obdobia) uznal za dostačujúcu. Podl’a uvedeného rozhodnutia SD EÚ prenášanie nárokov zamestnanca na dovolenku z dôvodu práceneschopnosti z roka na rok a ich kumulácia by už nenapĺňalo účel dovolenky. Neobmedzené spočítavanie nárokov na dovolenku podl’a SD EÚ môže zmarit’ aj základný účel dovolenky, ktorým je zotavenie po práci. Preto sa prenášanie nároku na dovolenku z dôvodu dočasnej práceneschopnosti pracovníka môže v národnom zákonodarstve členských štátov časovo presne ohraničit' (pozri bod 38 a bod 33 rozhodnutia). Súdny dvor nepredpokladá žiadnu paušálnu časovú hranicu. V prípade právnej veci KHS Súdny dvor 15 mesačnú hranicu po uplynutí referenčného obdobia považuje za primeranú pre uplatnenie a vyčerpanie nároku na dovolenku. V dôsledku toho s ohl’adom na samotný účel práva na platenú dovolenku za kalendárny rok, ktoré sa bezprostredne priznáva každému aj práceneschopnému pracovníkovi, ak je napr. práceneschopný počas niekol'kých po sebe nasledujúcich rokov, nemôže byt' oprávnený neobmedzene kumulovat' nároky na platenú dovolenku za kalendárny rok získané počas tohto obdobia (bod 34 rozhodnutia). Každé obdobie prenesenia dovolenky musí výrazne prekračovat' dĺžku referenčného obdobia, pre ktoré bolo priznané (bod 38 rozhodnutia). 'Toto obdobie musí rovnako chránit' zamestnávatel'a pred nebezpečenstvom neprimeraného kumulovania období neprítomnosti pracovníka na pracovisku a pred nepríjemnost’ami, ktoré z toho môžu vyplývat' pre organizáciu práce. Súdny dvor rozhodol, že článok 7 ods. 1 smernice 2003/88/ES o niektorých aspektoch organizácie pracovného času sa má vykladat' v tom zmysle, že nebráni vnútroštátnym ustanoveniam alebo vnútroštátnej praxi, akými sú napriklad kolektivne żmluvy, ktoré obmedzujú kumulovanie nárokov na platenú dovolenku za kalendárny rok práceneschopného zamestnanca počas niekol'kých po sebe nasledujücich referenčných obdobi tým, že stanovijú lehotu 15 mesiacov po uplynuti roka, kedy pracovnikovi vžniklo právo na dovolenku, po uplynuti ktorej zanikne nárok na platenú dovolenku za kalendárny rok.

\section{Zánik nároku práva na dovolenku za kalendárny rok}

Národná právna úprava členského štátu EÚ môže v iných prípadoch zakotvit' zánik nároku na dovolenku len v prípade, že samotný zamestnanec mal skutočnú možnost' si vyčerpat' dovolenku a napriek tomu tak neurobil (Schulz-Hoff-Stringer, bod 46 a nasl.).

Podl'a slovenskej pracovnoprávnej úpravy Zákonníka práce zamestnanec má zásadne vyčerpat' dovolenku do konca kalendárneho roka, v ktorom mu vznikol nárok. Ak si ju nemohol vyčerpat' v kalendárnom roku z naliehavých prevádzkových dôvodov alebo preto, že zamestnávatel’ neurčil jej čerpanie, alebo pre prekážky v práci, je zamestnávatel' povinný poskytnút' ju do konca nasledujúceho kalendárneho roka.

Prenášanie nároku na dovolenku je na rozdiel od vyššie uvedeného inak upravené v prípade nevyčerpania materskej dovolenky alebo rodičovskej dovolenky alebo dočasnej práceneschopnosti. Ak takúto dovolenku zamestnanec resp. zamestnankyňa nevyčerpá ani do konca nasledujúceho kalendárneho roka, nevyčerpanú dovolenku im zamestnávatel' 
poskytne po skončení materskej dovolenky alebo rodičovskej dovolenky, resp. po skončení dočasnej práceneschopnosti. Podl’a aktuálneho právneho stavu ak zamestnávatel' neurčil zamestnancovi čerpanie dovolenky najneskôr do 30. júna nasledujúceho kalendárneho roka tak, aby ju vyčerpal najneskôr do konca kalendárneho roka, dovolenku si môže určit' sám zamestnanec, ktorý má len oznamovaciu povinnost' voči zamestnávatel'ovi.

Zamestnávatel’ je zároveň povinný určit' zamestnancovi čerpanie aspoň štyroch týždňov dovolenky v kalendárnom roku, ak čerpaniu nebránia prekážky v práci na strane zamestnanca ( $\int 111$ ods. 1 ZP) tak, aby si ju zamestnanec mohol vyčerpat' vcelku a do konca príslušného kalendárneho roku.

Nadväzujúc na závery Súdneho dvora v právnej veci KHS doba do konca nasledujúceho kalendárneho roka (12 mesiacov) jedného roka na dočerpanie dovolenky za kalendárny rok po skončení roka, v ktorom pracovníkovi vznikol nárok na dovolenku tak, ako ju upravuje Zákonník práce SR, nie je v zmysle aktuálnej judikatúry SD EÚ dostačujúca. Podla bodu 40 právnej veci Neidel na to, aby bolo rešpektované právo na dovolenku, ktorého ciel’om je ochrana pracovníka, musí každé obdobie prenesenia dovolenky zohladňovat' špecifickú situáciu, v ktorej sa práceneschopný pracovník nachádza a ktorý je práceneschopný počas niekol'kých po sebe nasledujúcich referenčných období. Obdobie prenesenia minimálnej ročnej dovolenky musí pracovníkovi predovšetkým zabezpečit', že v prípade potreby bude mat' k dispozícii čas odpočinku, ktorý bude rozložitel'ný, plánovatel'ný a ktorý bude mat' dlhodobo k dispozícii, a ktorý musí podstatne prekračovat' dížku referenčného obdobia, pre ktoré právo na dovolenku bolo priznané (pozri tiež už citovaný rozsudok KHS, bod 38).

Zánik práva na minimálnu dovolenku za kalendárny rok zaručený článkom 7 smernice 2003/88/ES sú členské štáty oprávnené upravit’ uplynutím referenčného obdobia pod podmienkou, že pracovník, ktorému vzniklo právo na dovolenku za kalendárny rok, mal skutočne možnost' výkonu tohto práva. ${ }^{20}$ Podl'a výroku Súdneho dvora v právnej veci Sobczysszyn vnútroštátne predpisy členských štátov EÚ, ktoré by pracovníkovi neumožňovali po skončení dočasnej práceneschopnosti, ktorá trvala celé referenčné obdobie vyčerpat' si svoju dovolenku za kalendárny rok v neskoršom období, sú v rozpore s článkom 7 smernice 2003/88/ES.

\section{Trvanie minimálnej ročnej platenej dovolenky}

Aj ked’ smernica ustanovuje minimálne trvanie ročnej platenej dovolenky na štyri týždne, konkrétne neustanovuje spôsob vykonania tohto práva zo strany členských štátov, či budú členské štáty napríklad počítat’ minimálny rozsah ročnej platenej dovolenky $\mathrm{v}$ týždňoch alebo $\mathrm{v}$ pracovných dňoch či v hodinách. $\mathrm{V}$ tom majú členské štáty relatívne široký priestor pre vol'nú úvahu.

20 C-178/15, Sobçysşyn, zo dňa 30. 6. 2016; tiež právna vec Pereda, C-277/08, zo dňa 10. 9. 2009. 
Pokial’ ide o možné krátenie dovolenky v závislosti od rozsahu čiastočného pracovného úväzku, smernica nezakazuje krátenie dovolenky napríklad pri čiastočnom pracovnom úväzku. ${ }^{21} \mathrm{~V}$ zmysle existujúcej kontinuálnej judikatúry SD EÚ treba postupovat' podl’a zásady pro rata temporis, zakotvenej v smernici 1997/81/ES o čiastočnom pracovnom úväzku.

Aj v právnej veci Heimann a d’alšl2 Súdny dvor rozhodoval o probléme vplyvu práce na kratší pracovný úväzok na rozsah nároku na dovolenku, ktorý sa má považovat’ za primeraný odpracovanej dobe a nemožno naňho uplatnit' taký model čerpania dovolenky ako pri pracovnej neschopnosti zamestnanca. V odôvodnení SD EÚ uvádza, že pri čiastočnom pracovnom úväzku (Kurzarbeit) dochádza na strane zamestnanca aj zamestnávatel'a ku suspenzácii práv a povinnosti a počas vol'ného času má zamestnanec možnost' si oddýchnut' a zotavit' sa a uskutočňovat' rôzne vol'nočasové aktivity a nie je neschopný práce ako pri dôvode práceneschopnosti z dôvodu choroby. Krátenie nároku na ročnú platenú dovolenku z tohto dôvodu je oprávnené.

V právnej veci Brandes sa Súdny dvor EÚ zaoberal problémom určenia rozsahu dovolenky v prípade prechodu pracovníka z plného pracovného úväzku na čiastočný pracovný úväzok, kedy zo strany zamestnávatel'a je potrebné započítat’ nároky pracovníka počas trvania plného pracovného úväzku. ${ }^{23}$ Krátenie dovolenky pri prechode z plného pracovného úväzku na čiastočný pracovný úväzok je možné tak, že zamestnanec nesmie byt' znevýhodnený nezapočítaním svojich výhodnejších nárokov získaných ešte pred skrátením pracovného úväzku. Ide najmä o prípady, ked’ si zamestnanec nemohol vyčerpat' dovolenku v rámci príslušného roka, kedy mal plný pracovný úväzok alebo vyšší rozsah pracovného úväzku. Prenesené nároky na dovolenku ešte z času trvania plného pracovného úväzku alebo vyššieho rozsahu pracovného úväzku sa nesmú skrátit', ak neskôr došlo ku skráteniu pracovného úväzku zamestnanca.

Právne výpovede Súdneho dvora pretlmočené aj do rozhodnutia v právnej veci Heimann možno preniest' aj na iné prípady s výnimkou materskej, resp. rodičovskej dovolenky, ktoré sledujú iný účel v porovnaní s účelom nároku zamestnanca na ročnú platenú dovolenku v trvaní najmenej štyroch týždňov. Materská, resp. rodičovská dovolenka slúži k ochrane zdravia ženy počas tehotenstva a krátko po pôrode a táto dovolenka nesmie nevýhodne pôsobit' na minimálnu ročnú platenú dovolenku (Merino Goméz), preto nezapočítaný čas čerpania materskej dovolenky Súdny dvor neuznal za oprávnené. ${ }^{24}$

21 C-229/11 a C-230/11, Heimann a d'alši, zo dňa 8. 11. 2012, bod 32; ako aj rozhodnutie v právnej veci C-486/08, Zentralbetriebsrates der Landeskrankenbäuser Tirols, zo dňa 22. 4. 2010, bod 33.

22 C-229/11 a C-230/11, Heimann a d'alší, zo dňa 8. 11. 2012.

23 C-415/12, Brandes, zo dňa 13. 6. 2013.

24 C-342/01, Merino Gómez, zo dňa 18. 3. 2004, bod 37. 


\section{Krátenie dovolenky podl’a práva EÚ a ZP SR}

Podl’a dlhoročnej ustálenej judikatúry Súdneho dvora EÚ zamestnávatel nie je oprávnený krátit’ minimálnu výmeru dovolenky okrem prípadov kumulácie právnych nárokov z dôvodu dočasnej práceneschopnosti, prípadne z dôvodu, že zamestnancovi vypočíta kratšiu minimálnu dovolenku z dôvodu čiastočného pracovného úväzku.

Uvedenej požiadavke práva EÚ nezodpovedá slovenská pracovnoprávna úprava de lege lata, ktorá zamestnávatel'ovi umožňuje krátit' dovolenku zamestnancovi z viacerých právnych dôvodov aj pod rozsah minimálnej ročnej dovolenky zaručenej smernicou 2003/88/ES.

Zamestnancovi možno podl'a \109 ods. 1 ZP SR dovolenku krátit' za prvých 100 zameškaných pracovných dní o jednu dvanástinu a za každých d’alších 21 zameškaných pracovných dní rovnako o jednu dvanástinu, ak v kalendárnom roku pracovník nepracoval z dôvodu:

- výkonu mimoriadnej služby v období krízovej situácie alebo alternatívnej služby v čase vojny a vojnového stavu,

- čerpania rodičovskej dovolenky podl'a \166 ods. 2,

- dlhodobého uvol'nenia na výkon verejnej funkcie a na výkon odborovej funkcie podl'a $\int 136$ ods. 2 ZP,

- dôležitých osobných prekážok v práci podl’a \141 ods. 1 a ods. 3 písm. c).

Z dôvodu výkonu trestu odňatia slobody a pre väzbu možno zamestnancovi krátit' dovolenku za každých 21 takto zameškaných pracovných dní o jednu dvanástinu. Pri krátení dovolenky zamestnanca, ktorého pracovný pomer trval celý rok u toho istého zamestnávatel'a počas kalendárneho roka, zamestnávatel' je povinný podl'a existujúceho právneho stavu zamestnancovi poskytnút' dovolenku aspoň v dížke jedného týždňa, mladistvému zamestnancovi minimálne $\mathrm{v}$ dížke dvoch týždňov.

Dovolenku z dôvodu neospravedlnene zameškanej pracovnej zmeny možno krátit' v rozsahu jeden až dva dni. Neospravedlnené zameškania kratších častí jednotlivých zmien sa sčítajú.

Dovolenku za odpracované dni a dodatkovú dovolenku možno krátit' len z dôvodu neospravedlnene zameškanej pracovnej zmeny.

Krátenie minimálnej ročnej dovolenky z. dôvodu dočasnej pracovnej neschopnosti zamestnanca ako aj z dôvodu rodičovskej, resp. rodičovskej dovolenky, resp. z. dôvodu výkonu verejnej funkcie tak, ako sú upravené v Zákonniku práce SR, nie je v súlade s obsahom ani cielom článku 32 ods. 2 Charty základných práv EÚ, ani smernice 2003/88/ES a nekorešponduje súčasnej dlboročnej ustálenej judikatúre Súdneho dvora EÚ. V podstate pracounoprávna úprava ZP SR dovoluje zamestnávatelovi z. určitých dôvodov krátit’ dovolenku až na úroveñ jedného týždña, co je blboko pod hranicou minimálnej ročnej dovolenky podla článku 7 smernice 2003/88/ES. Minimálna štvortýždňová 
dovolenka za kalendárny rok pracovnikovi vaniká priamo z článku 7 smernice 2003/88/ES, ktorému SD EÚ priznal priamy právny účnok.

\section{Právo na dovolenku a zásada rovnakého zaobchádzania}

$\mathrm{Na}$ zásadu rovnakého zaobchádzania treba prihliadat', aj ked' samotný text smernice 2003/88/ES neobsahuje o tom výslovnú zmienku. Rozhodnutie Súdneho dvora EÚ v právnej veci Hay poukazuje na spojitost' právnej korektnosti právnej úpravy dovolenky vo vzt’ahu k dodržiavaniu zásady rovnakého zaobchádzania. ${ }^{25}$

Existujúca pracovnoprávna úprava Zákonníka práce SR umožňuje, aby zamestnanci, ktorí služobne odpracovali viac rokov, mali nižšiu výmeru dovolenky ako zamestnanci, ktorí síce dosiahli potrebný vek, ale odpracovali menej rokov v pracovnom pomere. V tom úprava Zákonníka práce SR pôsobí diskriminačne, pretože vek zamestnanca ustanovila za jediné kritérium nerovnakého zaobchádzania so zamestnancami pri určovaní výmery dovolenky. Základná výmera dovolenky podl’a Zákonníka práce SR je najmenej štyri týždne bez ohladu na vek a trvanie pracovného pomeru. Dovolenka vo výmere najmenej piatich týždňov prislúcha zamestnancovi, ktorý dovŕšil najmenej 33 rokov veku bez ohl'adu na dížku trvania pracovného pomeru.

Výmeru dovolenky niektorých skupín zamestnancov neovplyvňuje celková dížka trvania pracovného pomeru, ale druh práce, ktorú vykonávajú. Dovolenka riaditel'a školy, riaditel'a školského výchovnovzdelávacieho zariadenia, riaditel'a špeciálneho výchovného zariadenia a ich zástupcov, učitel’a, pedagogického asistenta, majstra odbornej výchovy a vychovávatel’a je najmenej osem týždňov.

Smernica 2003/88/ES v článku 7 garantuje právo pracovníka na minimálnu dovolenku za kalendárny rok v trvaní štyroch týždňov. Avšak v prípade, že členský štát prizná určitému okruhu osôb nárok výrazne nad rámec tohto ustanovenia smernice, v dôsledku priameho účinku článku 7 citovanej smernice ako aj dodržania zásady rovnakého zaobchádzania takýto rozsah dovolenky, patrí aj iným pracovníkom, inak by pôsobil diskriminačne. ${ }^{26}$

\section{Určenie čerpania dovolenky}

Článok 7 ods. 1 smernice 2003/88/ES neobsahuje žiadnu konkrétnu úpravu určenia čerpania dovolenky. Zaväzuje však členské štáty k prijatiu úpravy o presadení dovolenky za kalendárny rok. Pri určení čerpania dovolenky sa majú zohl’adňovat’ nielen záujmy zamestnanca ale aj záujmy zamestnávatel’a. Nárok na čerpanie dovolenky možno realizovat' aj počas práceneschopnosti zamestnanca z dôvodu choroby, ale zamestnanec

25 C-267/2012, Hay, zo dňa 12. 12. 2013, bod 47; tiež C-147/08, Römer, bod 52.

26 C-341/15, Maschek, zo dňa 20. 7. 2016, bod 23. 
nie je povinný čerpat' svoju ročnú platenú dovolenku v rozsahu štyroch týždňov počas trvania práceneschopnosti. V právnej veci Pereda Súdny dvor EÚ zdôraznil, že ak počas dovolenky zamestnanec ochorie, môže požiadat' zamestnávatel'a o dovolenku v inom čase. Dovolenku v takomto prípade je povinný zamestnávatel' presunút' na iné obdobie. ${ }^{27}$ V právnej veci Garcia bola pokladnícka paní Garcia v Carrefoure od novembra 2010 do júna 2011 práceneschopná. Počas jej práceneschopnosti bol prijatý plán dovoleniek firmy, ktorý pani Garcia nemohla splnit’ z dôvodu dočasnej práceneschopnosti. Návrh na dodatočné čerpanie dovolenky firma odmietla. Podl'a výroku Súdneho dvora EÚ, ak zamestnanec nemôže nastúpit' na dovolenku z dôvodu choroby, zamestnávatel'je povinný mu zaručit' čerpanie dovolenky v inom čase.

\section{Finančné zabezpečenie zamestnanca počas dovolenky}

Počas čerpania dovolenky má zamestnanec právo na peňažnú náhradu. O výške tejto náhrady sa smernica nezmieňuje. Ak má mzda zamestnancov viac obsahových súčastí, Súdny dvor EÚ požaduje preverenie výšky takejto náhrady mzdy, čo vyjadril v právnej veci Viliams a v právnej veci Lock. ${ }^{28}$ Rozhodnutie Súdneho dvora EÚ sa týkalo anglických pilotov British Airways, ktorých mzda sa skladala z troch súčastí. Jednu súčast' tvorila pevne určená mzda, druhú tvorili príplatky za nalietané hodiny a tretiu tvorili príplatky, ktoré piloti dostávali počas neprítomnosti v práci. Súdny dvor roz̧hodol, že pilot má nárok na nábradu mzdy za dovolenku nielen ako pevne dohodnutú súčast’ mzdy, ale tiež včitane v̌retkých troch časti mzdy. Podla bodu 21 rozhodnutia Súdneho dvora v právnej veci Viliams odmena za ročnú dovolenku má byt'v zásade vypočitaná tak, aby sa z̧hodovala s obvyklou pracounou odmenou pracovníka. Vnútroštátnemu súdu prináleží posúdit' skutočný vzt'ah rôznych zložiek tvoriacich celkovú odmenu pracovníka s výkonom úloh, ktoré mu prináležia podl’a jeho pracovnej zmluvy. Toto posúdenie je potrebné vykonat' na základe priemeru za referenčné obdobie, ktoré sa dá považovat' za reprezentatívne a s prihliadnutím na zásadu, podl’a ktorej smernica 2003/88/ES chápe právo na ročnú dovolenku a právo na získanie peňažnej náhrady pri jej čerpaní ako dve zložky jediného práva. ${ }^{29}$

Súdny dvor EÚ v právnej veci Maschek z roku 2016 sa vyjadril, že článok 7 smernice 2003/88/ES treba vykladat' tak, že tento článok smernice nekladie žiadnu inú požiadavku vžniku nároku na peñažnú nábradu okrem podmienky, vyplívajúcej zo skutočnosti, že skončil pracouný pomer a pracovník dovolenku nevyčrpal celú platenú dovolenku za kalendárny roke, na ktorú mal nárok ku dñu skončenia pracovnébo pomeru. ${ }^{30}$

\footnotetext{
27 C-277/08, Pereda, zo dňa 10. 9. 2009, body 22 a 32.

28 C-155/10, Wiliams a d'alší, zo dňa 15. 09. 2011.

29 Pozri rozsudky Robinson-Steele a i., bod 58 a rozsudok Schultz-Hoff a i., bod 60.

30 C-118/13, Bollacke, body 23 a 27.
} 
V rozpore s článkom 7 citovanej smernice je postup vnútroštátnej úpravy členských štátov, ak by sa peňažná náhrada pri skončení pracovného pomeru (aj pri kumulovaní nárokov) nevyplatila v prípade, že pracovník bol práceneschopný počas celého referenčného obdobia alebo obdobia na prenesenie dovolenky a z toho dôvodu nemohol vyčerpat' dovolenku a napr. by skončil pracovný pomer. V právnej veci KHS na rozdiel od vyššie uvedeného išlo o možnost' limitácie preplatenia dovolenky za kumulované obdobia v prípade, že pri uplatnení dovolenky stále trvá pracovný pomer. ${ }^{31}$

\section{Preplatenie nevyčerpanej dovolenky}

Preplatenie nevyčerpanej dovolenky za kalendárny rok v jej minimálnej výmere tak, ako ho zaručuje smernica 2003/88/ES, je možné len v prípade skončenia pracovného pomeru $\mathrm{V}$ trvajúcom pracovnoprávnom vzt’ahu je preplatenie minimálnej dovolenky za kalendárny rok neprípustné. ${ }^{32}$

Pri skončení pracovného pomeru pracovník nemusí zamestnávatel'ovi predkladat' osobitnú žiadost' o poskytnutie peňažnej náhrady za nevyčerpanú dovolenku. To platí aj v prípade zániku pracovného pomeru smrt’ou pracovníka (Bollacke 27) alebo v prípade skončenia pracovného pomeru z dôvodu odchodu pracovníka do dôchodku (C-337/10, Neidel, zo dňa 3. 5. 2012).

\section{Záver}

Takmer 30 rozsudkov Súdneho dvora EÚ v oblasti dovolenkového práva za obdobie ostatných rokov len vel'mi malou mierou ovplyvnilo existujúcu pracovnoprávnu normotvorbu Slovenskej republiky. Z vyššie uvedenej analýzy rozhodujúcich rozhodnutí Súdneho dvora EÚ z oblasti dovolenkového práva usudzujeme, že slovenský zákonodarca neprikladá judikatúre Súdneho dvora EÚ taký význam, aký si vyžaduje.

Po prijatí takmer 30 rozhodnutí Súdneho dvora EÚ zrejme už nastal čas, aby došlo k zmene existujúcej pracovnoprávnej úpravy dovolenky aj v Slovenskej republike nielen pokial ide o správne určenie osobného rozsahu viazaného na pracovníka, ale tiež o odstránenie podmienky odpracovania príslušných dní v kalendárnom roku, podmieňujúcej jej vznik v rozhodnom období, prehodnotenia krátenia dovolenky z dôvodu dočasnej pracovnej neschopnosti pracovníka ako aj z iných dôvodov, úpravy limitácie poskytnutia náhrady mzdy pri dlhotrvajúcej dočasnej práceneschopnosti pracovníka a nelimitácie týchto náhrad pri iných dôvodoch nevyčerpania dovolenky, ako aj d’alšie problémy, súvisiace s požiadavkami vyplývajúcimi z doterajšej rozhodovacej činnosti Súdneho dvora Európskej únie.

31 C-341/15, Maschek, bod 31.

32 C-155/10, Wiliams a d'alši, zo dňa 15. 9. 2011. 
Doterajšia pracovnoprávna úprava dovolenky tak, ako ju zakotvuje Zákonník práce Slovenskej republiky až na výnimky svojím obsahom akoby ignorovala doterajšiu rozhodovaciu činnost' Súdneho dvora EÚ, pretože opticky aj obsahom sa nepodobá právnej úprave štátu, ktorý je členským štátom Európskej únie. 